\title{
Genetic Diversity of the cagA gene of Helicobacter pylori strains from Sudanese Patients with Different Gastroduodenal Diseases
}

Hadeel Gassim Hassan, ${ }^{1,2,{ }^{*} \theta}$ Abeer Babiker Idris, ${ }^{2,3,}{ }^{*}$ Mohamed A. Hassan. ${ }^{3,4}$ Hisham N. Altayb, ${ }^{5}$ Kyakonye Yasin $^{6}$, Nazar Beirage ${ }^{7}$, Muzamil M. Abdel Hamid ${ }^{1 \theta}$

${ }^{1}$ Institute of Endemic Diseases, Medical Sciences Campus, University of Khartoum, Khartoum,Sudan

${ }^{2}$ Department of Medical Microbiology, Faculty of Medical Laboratory Sciences, University of Khartoum, Khartoum, Sudan

${ }^{3}$ Department of Bioinformatics, Africa city of technology, Khartoum, Sudan

${ }^{4}$ Department of Bioinformatics, DETAGEN Genetic Diagnostics Center, Kayseri, Turkey

${ }^{5}$ Department of Microbiology, College of Medical Laboratory Science, Sudan University of Science and Technology, Khartoum, Sudan

${ }^{6}$ Faculty of Pharmacy, International University of Africa, Khartoum, Sudan

${ }^{7}$ Department of Bioscience, Brunel London University, London

*These authors contributed equally to this work

${ }^{\theta}$ Corresponding author: mahdi@iend.org; hadeelgassimhassan@gmail.com 


\begin{abstract}
Background: There is an increase in the prevalence of Helicobacter pylori infection in Sudan, accompanied by a high incidence of upper gastrointestinal malignancy. The cytotoxin-associated gene $\operatorname{cagA}$ gene is a marker of a pathogenicity island (PAI) in H. pylori and plays a crucial role in determining the clinical outcome of Helicobacter infections.
\end{abstract}

Objective: This study aimed to determine the frequency and heterogeneity of the cagA gene of H. pylori and correlate the presence of $\operatorname{cagA}$ gene with clinical outcomes.

Materials and methods: Fifty endoscopy biopsies were collected from Fedail and Soba hospitals in Khartoum state. DNA was extracted using the Guanidine chloride method followed by PCR to amplify $16 S r R N A$ and cagA gene of $H$. pylori using specific primers. DNA amplicons of $\operatorname{cag} A$ gene were purified and sequenced. Bioinformatics and statistical analysis were done to characterize and to test the association between $\operatorname{cag} A$ gene and gastric complications.

Results: $\operatorname{Cag} A$ gene was detected in 20/37(54\%) of the samples that were found positive for $H$. pylori. There was no association between endoscopy finding and the presence of the cagA gene $(\mathrm{p}=0.225)$. Specific amino acid variations were found at seven loci related to strains from a patient with duodenitis, gastric ulcer, and gastric atrophy (R448H, T457K, S460L, IT463464VA, D470E, A482Q, KNV490-491-492TKT) while mutations in cancerous strain were A439P, T457P, and H500Y.

Conclusion: Disease-specific variations of cagA of $H$. pylori strains, in the region of amino acid residues 428-510, were evident among Sudanese patients with different gastroduodenal diseases. A novel mutation $(\mathrm{K} 458 \mathrm{~N})$ was detected in a patient with duodenitis, which affects the positive electrostatic surface of $\operatorname{cagA}$. Phylogenetic analysis showed a high level of diversity of $\operatorname{cag} A$ from Sudanese H. pylori strains.

Keywords: H.pylori, cagA gene diversity, Sudan, virulence factors, Insilco 


\section{Introduction}

Helicobacter pylori (H. pylori) a bacterium is responsible for various gastrointestinal diseases, including gastritis, peptic ulcers, frequent bleeding events, gastric mucosa-associated lymphoid tissue (MALT) lymphoma, and carcinoma. ${ }^{(1,2)}$. A majority of infected individuals with $H$. pylori are asymptomatic ${ }^{(3,4)}$ and despite treatment, some infected patients may not clear the infection, thus leading to chronic complication. The possible reason for the various outcomes of $H$. pylori infection may relate to the variations in virulence factors of $H$. pylori strains in addition to host, environment, and dietary factors. ${ }^{(5)}$

The cytotoxic associated gene $\mathrm{A}(\operatorname{cag} A)$ is one of the most virulence factors which has been implicated as a possible marker to distinguish variations in the virulence of H. pylori strains. ${ }^{(6,}$ ${ }^{7)}$ The $\operatorname{cag} A$ gene encodes a $120-145 \mathrm{kDa}$ protein, and it is located within the $\sim 40 \mathrm{~kb}$ pathogenicity island (cag PAIs). ${ }^{(5)}$ The cag PAIs expresses a type IV secretion systems (T4SS) which introduces the cagA effector protein into the host target cells where it undergoes tyrosine phosphorylation by $\mathrm{Src}$ and $\mathrm{Ab} 1$ kinases $^{(8)}$. The $\operatorname{cagA}$ protein is actively involved in the regulation of the spreading, migration, and adhesion of cells known to play a decisive role in mutagenic signal transduction, and stimulation of phosphatase activity also it induces vacuolation of primary human mucosal epithelial cells. ${ }^{(9,10)} \operatorname{CagA}$ is the most intensely studied since its first association with the risk of gastric cancer. ${ }^{(10)}$ Various studies have documented that infection with $H$. pylori strains expressing cagA was correlated with the development of severe gastrointestinal diseases such as atrophic gastritis, peptic ulcer, and gastric carcinoma. ${ }^{(11-15)}$

H. pylori infect about half of the world population, but only a subset of $1 \%$ to $2 \%$ of those infected individuals will develop gastric malignancies. ${ }^{(1)}$ The prevalence in developed countries is low $25 \%$, a contrast to developing countries where the incidence is very high up to $90 \%{ }^{(4,16 \text {, }}$ 17) and the infection occurring early in life and tending to persist for longtime unless treated. ${ }^{(18)}$ There is an increased in the prevalence of $H$. pylori infection in Sudan accompanied with high incidence of upper gastrointestinal malignancy (13.2\%) when compared to previous study reported by Elhadi et al. ${ }^{(19)}$ Therefore, the aim of this study was to determine the frequency and heterogeneity of $\operatorname{cagA}$ and its correlation with severe gastroduodenal diseases among Sudanese patients. To our knowledge, this is the first study in Sudan that reports the association of cagA and its heterogeneity to clinical outcomes of $H$. pylori infection. The molecular characterization 
of cagA and its mutations in amino acid sequence 428-510 were analyzed by using in silico tools. According to the X-ray crystallographic analysis of the N-terminal cagA fragment (residues 1876) of the reference strain (H. pylori strain 26695), ${ }^{(20)}$ amino acid sequence 428-510is located in domain II which tethers CagA to the plasma membrane by interacting with membrane phosphatidylserine. It is characterized by a sizeable antiparallel $\beta$-sheet and an insertion of a subdomain (residues $370-446$ ) between $\beta 5$ and $\beta 8$ strands. ${ }^{(21)}$

\section{Materials and methods}

2.1 Study design and study population

A prospective cross -sectional hospital-based study was conducted in Fedial and Soba hospitals in Khartoum state between February and May 2016. Patients who referred to hospitals for upper gastrointestinal tract endoscopy and suspected to be infected with $H$. pylori were enrolled. Patients who had received nonsteroidal anti-inflammatory drugs and proton pump inhibitor (PPI) were excluded from the study, and none of the patients had recently been prescribed antibiotics.

\subsection{Clinical Samples}

The ethical approval was granted by the Institute of Endemic Diseases. All study participants completed informed consent forms prior to the commencement in the study.

A total of fifty patients were selected for the study, twenty-five of these patients were males, and twenty-five were females. Specimens were obtained from all patients and tentatively diagnosed by the gastroenterologist as having a helicobacter infection. The samples were labeled and transferred to the laboratory for DNA analysis. Patient endoscopy findings included gastritis, gastric ulcer, atrophy gastric, gastritis, and duodenitis.

\subsection{Extraction of DNA and PCR analysis}

DNA was extracted using Guanidine chloride method ${ }^{17}$. PCR amplification was done using specific primers for $H$. pylori $16 \mathrm{~S}$ rRNA gene F:5'GCGACCTGCTGGAACATTAC-3' and R:5'GCGTTAGCTGCATTACTGGAGA-3'. A ready master pre-mix (Maxime, iNtRON BIOTECHNOLOGY, Korea) was used. A total volume of $25 \mu 1$ contained a1 $\mu$ l of each primer 
(10 pmole), $1 \mu \mathrm{l}$ of DNA template and $22 \mu \mathrm{l}$ of de-ionized sterile water. A PCR reaction was carried out using a thermocycler (SensoQuest, Germany) following a protocol described by William et al. ${ }^{(22)}$ CagA gene was amplified using primer set F:5'ATAATGCTAAATTAGACAACTTGAGCGA-3'

R:5'TTAGAATAATCAACAAACATCACGCCA-3' using a method defined previously. (23) PCR amplicons were analysed on $1.5 \%$ Agarose gel stained with $1 \mu$ l ethidium bromide $(10 \mathrm{mg} / \mathrm{ml})$. Electrophoresis was done at $90 \mathrm{~V}$ and $25 \mathrm{~mA}$. DNA bands were estimated using a 100bp DNA ladder (iNtRON BIOTECHNOLOGY, Korea European Biotech). The bands were visualized using Gel documentation systemBioDoc-It UVP, Cambridge UK). DNA purification and sequencing was performed commercially at Macrogen Inc, Korea.

\subsection{Statistical and Bioinformatics analysis}

Data were analyzed using IBM SPSS Statistical software (Statistical Package for the Social Sciences). Chi-square was used to test the association of gastric complications with cagA gene. The nucleotide sequences of the cagA gene were compared for genetic diversity using nucleotide BLAST (http: //blast.ncbi.nlm.nih.gov/Blast.cgi). ${ }^{(24)}$ from NCBI, Highly similar sequences were retrieved and subjected to multiple sequence alignment using Clustal Omega - EMBL-EBI. ${ }^{(25)}$ For nucleotides translation, evolutionary analysis and building a phylogenetic tree, GeneMarks ${ }^{(26)}$ and jalview ${ }^{(27)}$ were used, respectively. Modeling of 3D structural Protein was done by sending the protein sequence of the reference strain $(H \text {. pylori strain } 26695)^{(20)}$ to raptor X online server. ${ }^{(28)}$ Structural homology modeling of this reference strain (NP_207343) was done due to the existence of short disordered stretches, common in all crystal forms, ${ }^{(21,29-31)}$ which their electron densities are not observed in any crystal such as residues 479-488 that is located in our region (residues 425-510). The Predicted structure was analyzed by using UCSF Chimera (version $1,11,2){ }^{(32)}$

The nucleotide sequences of the $\operatorname{cag} A$ genes were deposited in the GenBank database (National Center for Biotechnology Information; https://www.ncbi.nlm.nih.gov/), Accession number of the strains with their clinical outcomes are presented in Table 1. 
medRxiv preprint doi: https://doi.org/10.1101/19007435; this version posted September 27, 2019. The copyright holder for this preprint (which was not certified by peer review) is the author/funder, who has granted medRxiv a license to display the preprint in perpetuity.

It is made available under a CC-BY-ND 4.0 International license .

Table 1. Shows the accession number of the stains with their clinical outcomes

\begin{tabular}{|c|c|c|}
\hline Name of strain & Outcome & Accession number \\
\hline Sudan-1 & Normal finding & MK074988 \\
\hline Sudan-2 & Normal finding & MK074989 \\
\hline Sudan-3 & Normal finding & MK074990 \\
\hline Sudan-4 & Gastritis & KX879074 \\
\hline Sudan-5 & Gastritis & MK074991 \\
\hline Sudan-6 & Gastritis & MK074992 \\
\hline Sudan-7 & Gastritis & MK074993 \\
\hline Sudan-8 & Gastritis & KX879073 \\
\hline Sudan-9 & Duodenitis & МK074994 \\
\hline Sudan-10 & Duodenitis & KX879075 \\
\hline Sudan-11 & Cancer & MK074995 \\
\hline Sudan-12 & Gastric atrophy & MK074996 \\
\hline Sudan-13 & Gastric ulcer & MK074997 \\
\hline Sudan-14 & Gastric ulcer & MK074998 \\
\hline Sudan-15 & Gastric ulcer & MK074999 \\
\hline Sudan-16 & Gastric ulcer & KX879072 \\
\hline
\end{tabular}




\section{Results}

\subsection{Endoscopy finding}

Endoscopic examination was performed on all patients $(n=50)$. Abnormal endoscopic finding was observed in $42 / 50(84 \%)$ of the patients, out of this $18 / 50(36 \%)$ were diagnosed with gastritis, 3/50(6\%) with duodenitis, 12/50(24\%) with gastric ulcers, 2/50(4\%) with atrophy gastric, and 7/50(14\%) with gastritis duodenitis.

\subsection{Positive biopsy for $H$. pylori (16S rRNA)}

Fifty $(n=50)$ samples were tested for the presence of $16 \mathrm{~S}$ rRNA, 37/50(74\%) were found to be positive, and 13/50(26\%) were found to be negative for $H$. pylori. (Figure 1).

\subsection{Frequency of $\operatorname{cag} A$ gene}

The $\operatorname{cagA}$ gene frequency was found to be 20/37 (54\%) among positive samples for (16S rRNA) of $H$. pylori. In gastric atrophy patients, it was found to be $2 / 20(10 \%), 4 / 20(20 \%)$ in normal findings endoscopy patients,6/20(30\%) in gastric ulcer patients,2/20(10\%) in duodenitis patients, and gastritis patients were found to be $4 / 20(25 \%)$. (Table 2).

\subsection{Variations of amino acid among $\operatorname{cag} A$ protein}

In comparison with strain 26695 (reference strain), disease-specific variations at different $\operatorname{cag} A$ loci were detected at a region in domain II (amino acid sequence 428-510) as illustrated (Figure2 and Figure 4). The mutations in amino acids R448H, T457K, S460L, IT463-464VA, D470E, A482Q, and KNV490-491-492TKT were found in cagA of duodenitis, gastric ulcer and gastric atrophy caused strains while mutations in cancerous strain were A439P, T457P, and H500Y. The amino acids at 467 and 497 loci were mutated in all strains regardless of gastrointestinal diseases. 
medRxiv preprint doi: https://doi.org/10.1101/19007435; this version posted September 27, 2019. The copyright holder for this preprint (which was not certified by peer review) is the author/funder, who has granted medRxiv a license to display the preprint in perpetuity.

It is made available under a CC-BY-ND 4.0 International license .

Table 2. Frequency of cagA gene in $H$. pylori strains from various gastroduodenal disease.

\begin{tabular}{cccc}
\hline $\begin{array}{c}\text { Endoscopic } \\
\text { finding }\end{array}$ & $\begin{array}{c}\text { Endoscopy } \\
\text { finding frequency } \%\end{array}$ & $\begin{array}{c}\text { Number of specimen } \\
\text { +ve)16SrRNA }\end{array}$ & $\begin{array}{c}\text { Number of cag A } \\
\text { positive strains \% }\end{array}$ \\
\hline Normal & $8(16 \%)$ & $\mathbf{( N = 3 7 )}$ & $4(20 \%)$ \\
Duodenitis & $3(6 \%)$ & $5(14 \%)$ & $2(10 \%)$ \\
Ulcer & $12(24 \%)$ & $3(8 \%)$ & $6(30 \%)$ \\
Gastritis & $18(36 \%)$ & $10(27 \%)$ & $4(20 \%)$ \\
Gastroduodenitis & $7(14 \%)$ & $10(27 \%)$ & $1(5 \%)$ \\
Atrophy gastric & $2(4 \%)$ & $6(16 \%)$ & $2(10 \%)$ \\
Cancer & $1(2 \%)$ & $2(5 \%)$ & $1(5 \%)$ \\
\hline
\end{tabular}

\subsection{Phylogenetic analysis}

Phylogenetic analysis of cagA with global H. pylori strains revealed that the Sudanese H.pylori strains were divided into two major groups. One group involves strains that cause duodenitis, gastric ulcer, and gastric atrophy while cancerous strain belongs to another common ancestor, as illustrated in Figure5.

\section{Discussion}

In this study, the analysis of amino acid sequence 425-510 of cagA indicated that the mutations at this region are distinguishable between gastrointestinal diseases. This indication is in agreement with the result obtained by Sung Soo et al. , 2015 which suggested that the mutations of cagA of $H$. pylori, especially in C-terminus, are distinguishable between duodenal ulcer and gastric carcinoma. ${ }^{(33)}$ In Sudan-9 strain that caused duodenitis, a novel mutation in lysine residue 
at 458 which constitutes with other lysine residues located in $\beta 9, \beta 10$ and $\alpha 18$; and two arginine residues (R624 and R626) the basic amino-acid cluster. ${ }^{(21)}$ The basic amino-acid cluster provides a positive electrostatic surface potential, which is crucial for the CagA and phospholipid of the plasma membrane interaction. This interaction is essential for the delivery of CagA into host cells and also for the localization of delivered CagA to the inner face of the plasma membrane in epithelial cells. ${ }^{(34)}$

Specific amino acid variations were found at seven loci (R448H, T457K, S460L, IT463-464VA, D470E, A482Q, KNV490-491-492TKT) which were related to strains detected in patients with gastric atrophy, gastric ulcer, and duodenitis. These mutations were also detected in Japanese and American strains isolated from patients with atrophy (Oki120, Oki112, Oki128, and Ok139 strains) ${ }^{(35,36)}$ and duodenal ulcer (Oki898 and Ok204 and J99 strains). ${ }^{(35-37)}$ However, there are some strains of $H$. pylori implicated in both diseases gastric and duodenal ulcer (e.g., Germany strain UH44); ${ }^{(38)}$ and maybe Sudanese strains are one of them. Two strains (Sudan-1 and Sudan3) were detected from patients with normal gastroduodenal finding had the same mutations of gastric ulcer strains. While the third one (Sudan-2) and gastritis strains share the same mutations of cancerous strain (A439P, T457P, N468K, and H500Y). The infection of those patients could be a new type and need more time to reflect the complications or could be due to host/environmental factors that delay the appearance of complications. ${ }^{(39-41)}$ This finding is partially in agreement with the result obtained by Masahiko et al., that the Amino acid frequency of gastritis samples seems to be intermediate between gastric cancer and MALT lymphoma samples. ${ }^{(42)}$ In contrast, two Japanese strains (NCTC11637 and NCTC11638) isolated from patients with gastritis do not have any mutations in this region (amino acid residues 428-510) except $\mathrm{N} 467 \mathrm{G}$ which was found in all our sequences in regardless to gastroduodenal diseases. ${ }^{(43)}$

In this study, the frequency of $H$. pylori infection among endoscopics was found to be $37 / 50$ (74\%) using PCR; this result was higher compared to the prevalence of 18/81 (22.2\%) reported by Mona et al., 2015 had been used culture methods. ${ }^{(44)}$ Recently, assays based on PCR have been used to detect $H$. pylori DNA and its virulence genes in gastric biopsies with high specificity and quick results have been obtained without the requirement for special transport conditions. However, the presence of the cagA gene has been confirmed in 54\% of the Sudanese H. pylori strains. The frequency of cagA positive $H$. pylori varies from one geographic region to 
another. In Sri Lanka is $48 \%$, in the Netherlands is $67 \%$, in Germany is $72 \%$, in the United States is $81 \%$, in Nigeria is $93 \%$ and in Korea is $97 \%$. ${ }^{(2)}$

The association between the genotype of $\operatorname{cag} A$ and clinical outcome was examined. There was no significant association between the genotype of $\operatorname{cag} A$ and clinical outcome $\left(\mathrm{X}^{2}=1.567^{\mathrm{a}} ; \mathrm{df}=1\right.$; $\mathrm{p}=0.225$ ). This finding agrees with the study conducted by Wen et.al, 2004 in East Asia, ${ }^{(45)}$ and disagrees with a study that was done in Chinese population that showing $95 \%$ positive for cagA gene among patients with peptic ulcer disease and $100 \%$ with chronic gastritis. ${ }^{(46)}$ This is could be related to geographic strain distribution; therefore more studies should be considered to include more sample size include

\section{Conclusion}

Disease-specific variation of CagA of $H$. pylori strains, in the region of amino acid residues 428510, are found among Sudanese patients. A novel mutation (K458N) was detected in the basic amino-acid cluster, which provides a positive electrostatic surface for CagA. Phylogenetic analysis showed a high level of diversity of cagA among Sudanese H. pylori strains.

\section{Acknowledgements:}

Funding: This study was funded by TWAS research grant No: 17-516 RG/BIO/AF/AC_GFR3240297732

Conflicts of Interest: The authors declare that there is no conflict of interest in this research work.

\section{References}

1. Testerman TL, Morris J. Beyond the stomach: an updated view of Helicobacter pylori pathogenesis, diagnosis, and treatment. World J Gastroenterol. 2014;20(36):12781-808.

2. Bindayna KM, Al Baker WA, Botta GA. Detection of Helicobacter pylori cagA gene in gastric biopsies, clinical isolates, and faeces. Indian J Med Microbiol. 2006;24(3):195-200. 
3. Abdallah TM, Mohammed HB, Mohammed MH, Ali AAA. Sero-prevalence and factors associated with Helicobacter pylori infection in Eastern Sudan. Asian Pacific Journal of Tropical Disease. 2014;4(2):115-9.

4. Afihene MKY, Denyer M, Amuasi JH, Boakye I, Nkrumah K. Prevalence of Helicobacter pylori and Endoscopic findings among dyspeptics in Kumasi, Ghana. Open Science Journal of Clinical Medicine. 2014;2(3): 63-8.

5. Matsunari O, Shiota S, Suzuki R, Watada M, Kinjo N, Murakami K, et al. Association between Helicobacter pylori virulence factors and gastroduodenal diseases in Okinawa, Japan. Journal of clinical microbiology. 2012;50(3):876-83.

6. Hoshino FB, Katayama K, Watanabe K, Takahashi S, Uchimura H, T. A. Heterogeneity found in the cagA gene of Helicobacter pylori from Japanese and non-Japanese isolates. J Gastroenterol. 2000;35(12):890-7.

7. Crabtree JE, Covacci A, Farmery SM, Xiang Z, Tompkins DS, Perry S, et al. Helicobacter pylori induced interleukin-8 expression in gastric epithelial cells is associated with CagA positive phenotype. Journal of clinical pathology. 1995;48(1):41-5.

8. Salama N, Guillemin K, McDaniel TK, Sherlock G, Tompkins L, Falkow S. A wholegenome microarray reveals genetic diversity among Helicobacter pylori strains. Proceedings of the National Academy of Sciences of the United States of America. 2000;97(26):14668-73.

9. Kim JM, Kim JS, Jung HC, Song IS, Kim CY. Virulence factors of Helicobacter pylori in Korean isolates do not influence proinflammatory cytokine gene expression and apoptosis in human gastric epithelial cells, nor do these factors influence the clinical outcome. Journal of gastroenterology. 2000;35(12):898-906.

10. Olbermann P, Josenhans C, Moodley Y, Uhr M, Stamer C, Vauterin M, et al. A global overview of the genetic and functional diversity in the Helicobacter pylori cag pathogenicity island. PLoS genetics. 2010;6(8):e1001069-e.

11. Peek RM, Jr., Miller GG, Tham KT, Perez-Perez GI, Zhao X, Atherton JC, et al. Heightened inflammatory response and cytokine expression in vivo to cagA+ Helicobacter pylori strains. Laboratory investigation; a journal of technical methods and pathology. 1995;73(6):76070. 
12. Navaglia F BD, Piva MG, Brigato L, Stefani A, Dal Bò N, Di Mario F, Rugge M, Plebani M. Helicobacter pylori cytotoxic genotype is associated with peptic ulcer and influences serology. The American journal of gastroenterology. 1998;93(2):227-30.

13. Gunn MC, Stephens JC, Stewart JA, Rathbone BJ, West KP. The significance of cagA and vacA subtypes of Helicobacter pylori in the pathogenesis of inflammation and peptic ulceration. Journal of clinical pathology. 1998;51(10):761-4.

14. Basso D, Navaglia F, Brigato L, Piva MG, Toma A, Greco E, et al. Analysis of Helicobacter pylori vacA and cagA genotypes and serum antibody profile in benign and malignant gastroduodenal diseases. Gut. 1998;43(2):182-6.

15. Rudi J, Rudy A, Maiwald M, Kuck D, Sieg A, Stremmel W. Direct determination of Helicobacter pylori vacA genotypes and cagA gene in gastric biopsies and relationship to gastrointestinal diseases. The American journal of gastroenterology. 1999;94(6):1525-31.

16. Holcombe C. Helicobacter pylori: the African enigma. Gut. 1992;33:429-31.

17. Quek C, Pham ST, Tran KT, Pham BT, Huynh LV, Luu NB, et al. Antimicrobial susceptibility and clarithromycin resistance patterns of Helicobacter pylori clinical isolates in Vietnam. F1000Research. 2016;5:671.

18. Rowland M, Drumm B. Clinical significance of Helicobacter infection in children. $\mathrm{Br}$ Med Bull. 1998;54(1):95-103.

19. AA E, HO M, TH M, OS M, HA E. Pattern of Endoscopic Findings of Upper Gastrointestinal Tract in Omdurman Teaching. Sudan JMS 2004;9(2):71-4.

20. Xu S, Zhang C, Miao Y, Gao J, Xu D. Effector prediction in host-pathogen interaction based on a Markov model of a ubiquitous EPIYA motif. BMC genomics. 2010;11 Suppl 3(Suppl 3):S1-S.

21. Hayashi T, Senda M, Morohashi H, Higashi H, Horio M, Kashiba Y, et al. Tertiary structure-function analysis reveals the pathogenic signaling potentiation mechanism of Helicobacter pylori oncogenic effector CagA. Cell host \& microbe. 2012;12(1):20-33.

22. Gramley WA, Asghar A, Frierson HF, Jr., Powell SM. Detection of Helicobacter pylori DNA in fecal samples from infected individuals. Journal of clinical microbiology. 1999;37(7):2236-40.

23. Walencka M, Gonciarz W, Mnich E, Gajewski A, Stawerski P, Knapik-Dabrowicz A, et al. The microbiological, histological, immunological and molecular determinants of Helicobacter 
pylori infection in guinea pigs as a convenient animal model to study pathogenicity of these bacteria and the infection dependent immune response of the host. Acta biochimica Polonica. 2015;62(4):697-706.

24. Altschul SF, Madden TL, Schäffer AA, J Zhang ZZ, Miller W, Lipman DJ. Gapped BLAST and PSI-BLAST. A new generation of protein database search programmes. Nucleic Acids Res. 1997;25(17):3389-402.

25. McWilliam H, Li W, Uludag M, Squizzato S, Park YM, Buso N, et al. Analysis Tool Web Services from the EMBL-EBI. Nucleic Acids Res. 2013;41(Web Server issue): W597-600.

26. Besemer J, Lomsadze A, Borodovsky M. GeneMarkS: a self-training method for prediction of gene starts in microbial genomes. Implications for finding sequence motifs in regulatory regions. Nucleic Acids Res. 2001;29(12):2607-18.

27. Waterhouse AM, Procter JB, Martin DMA, Clamp M, Barton GJ. Jalview Version 2--a multiple sequence alignment editor and analysis workbench. Bioinformatics (Oxford, England). 2009;25(9):1189-91.

28. Källberg M, Wang H, Wang S, Peng J, Wang Z, Lu H, et al. Template-based protein structure modeling using the RaptorX web server. Nature Protocols. 2012;7:1511.

29. Nesic D, Miller MC, Quinkert ZT, Stein M, Chait BT, Stebbins CE. Helicobacter pylori CagA inhibits PAR1-MARK family kinases by mimicking host substrates. Nature structural \& molecular biology. 2010;17(1):130-2.

30. Kaplan-Turkoz B, Jimenez-Soto LF, Dian C, Ertl C, Remaut H, Louche A, et al. Structural insights into Helicobacter pylori oncoprotein CagA interaction with betal integrin. Proceedings of the National Academy of Sciences of the United States of America. 2012;109(36):14640-5.

31. Nesic D, Buti L, Lu X, Stebbins CE. Structure of the Helicobacter pylori CagA oncoprotein bound to the human tumor suppressor ASPP2. Proceedings of the National Academy of Sciences of the United States of America. 2014;111(4):1562-7.

32. Pettersen EF, Goddard TD, Huang CC, Couch GS, Greenblatt DM, Meng EC, et al. UCSF Chimera--a visualization system for exploratory research and analysis. Journal of computational chemistry. 2004;25(13):1605-12. 
33. Kim SS, Cheung DY, Park S-H. Differences of mutation of helicobacter pylori cagA gene isolated from duodenal ulcer and gastric cancer. Journal of Clinical Oncology. 2015;33(3_suppl):69-.

34. Murata-Kamiya N, Kikuchi K, Hayashi T, Higashi H, Hatakeyama M. Helicobacter pylori exploit host membrane phosphatidylserine for delivery, localization, and pathophysiological action of the CagA oncoprotein. Cell host \& microbe. 2010;7(5):399-411.

35. Satou K, Shiroma A, Teruya K, Shimoji M, Nakano K, Juan A, et al. Complete Genome Sequences of Eight Helicobacter pylori Strains with Different Virulence Factor Genotypes and Methylation Profiles, Isolated from Patients with Diverse Gastrointestinal Diseases on Okinawa Island, Japan, Determined Using PacBio Single-Molecule Real-Time Technology. Genome announcements. 2014;2(2).

36. Yamazaki S, Yamakawa A, Okuda T, Ohtani M, Suto H, Ito Y, et al. Distinct diversity of vacA, cagA, and cagE genes of Helicobacter pylori associated with peptic ulcer in Japan. Journal of clinical microbiology. 2005;43(8):3906-16.

37. Beaulaurier J, Zhang XS, Zhu S, Sebra R, Rosenbluh C, Deikus G, et al. Single moleculelevel detection and long read-based phasing of epigenetic variations in bacterial methylomes. Nature communications. 2015;6:7438.

38. Backert S, Schwarz T, Miehlke S, Kirsch C, Sommer C, Kwok T, et al. Functional analysis of the cag pathogenicity island in Helicobacter pylori isolates from patients with gastritis, peptic ulcer, and gastric cancer. Infection and immunity. 2004;72(2):1043-56.

39. Testerman TL, Morris J. Beyond the stomach: An updated view of Helicobacter pylori pathogenesis, diagnosis, and treatment. World journal of gastroenterology. 2014;20(36):12781808.

40. D. G. Solving the African enigma: parasites may have their place. Gastroenterology. 2000;119(3):611.

41. Kidd M, Louw JA, Marks IN. Helicobacter pylori in Africa: Observations on an 'enigma within an enigma'. Journal of Gastroenterology and Hepatology. 1999;14(9):851-8.

42. Hashinaga M, Suzuki R, Akada J, Matsumoto T, Kido Y, Okimoto T, et al. Differences in amino acid frequency in $\mathrm{CagA}$ and VacA sequences of Helicobacter pylori distinguish gastric cancer from gastric MALT lymphoma. Gut pathogens. 2016;8:54. 
medRxiv preprint doi: https://doi.org/10.1101/19007435; this version posted September 27, 2019. The copyright holder for this preprint (which was not certified by peer review) is the author/funder, who has granted medRxiv a license to display the preprint in perpetuity.

It is made available under a CC-BY-ND 4.0 International license .

43. Achtman M, Azuma T, Berg DE, Ito Y, Morelli G, Pan ZJ, et al. Recombination and clonal groupings within Helicobacter pylori from different geographical regions. Molecular microbiology. 1999;32(3):459-70.

44. Mamoun M, M ES, Enan KA, Abdo AE, Hassan MA. Molecular Identification Of 16s Ribosomal RNA Gene of Helicobacter pylori Isolated from Gastric Biopsies in Sudan. American Journal of Microbiological Research. 2015;3(2):50-4.

45. Zhou W, Yamazaki S, Yamakawa A, Ohtani M, Ito Y, Keida Y, et al. The diversity of vacA and cagA genes of Helicobacter pylori in East Asia. FEMS immunology and medical microbiology. 2004;40(1):81-7.

46. Pan Z, Bart A, Feller M, Xiao S, Tytgat G, J. N. cagA -Positive Helicobacter pylori Populations in China and The Netherlands Are Distinct. Tailieuvn. 1998;66:1822-6 
medRxiv preprint doi: https://doi.org/10.1101/19007435; this version posted September 27, 2019. The copyright holder for this preprint (which was not certified by peer review) is the author/funder, who has granted medRxiv a license to display the preprint in perpetuity.

It is made available under a CC-BY-ND 4.0 International license .

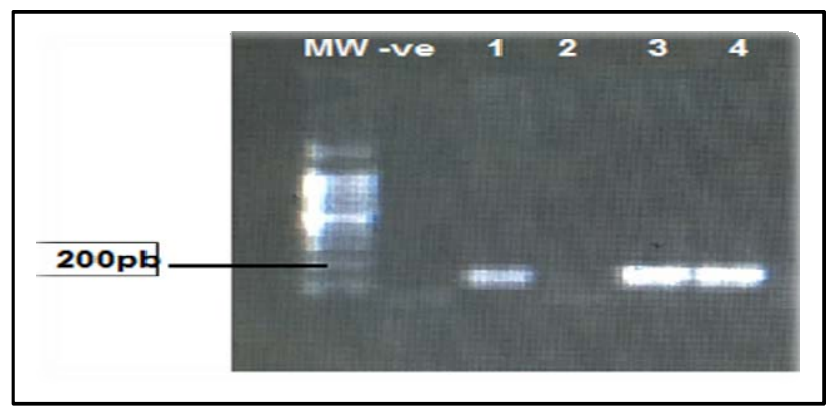

Figure 1: Amplified H. pylori16SrRNAgene PCR products from endoscopy biopsy. Lane 1: negative control (1), lanes $(2,4,5)$ is 16srRNAof H.pylori positive (168pb); MW: 100 bp DNA molecular weight marker 


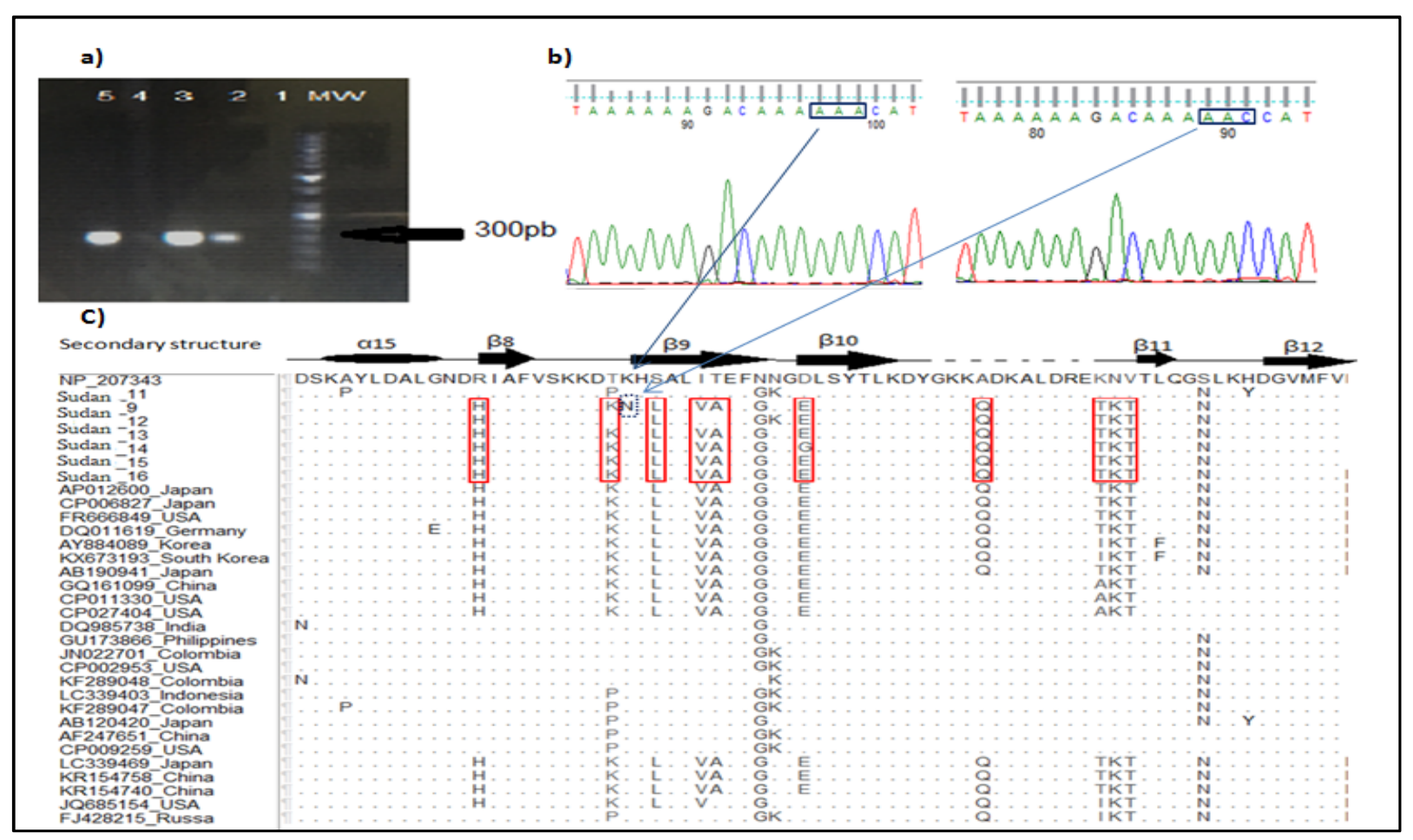

Figure 2: a) PCR gel showing bands corresponding to the H. pylori cagA gene from endoscopy biopsy. Lane 1: negative control (1), lanes 2,3,5 are Cag A positive genes of $H$. pylori (298pb), lane 4 negative sample.MW: 100bpDNA molecular weight marker. b) Shows the sequence chromatogram of codon 458 in normal finding and duodenitis causing strains, respectively by using Finch TV. c) Multiple sequence alignment of cagA gene sequences with other selected global strains obtained from GenBank. The different loci are shown in black letters, and white dots indicate similarity. The red boxes highlight amino acid variations at seven loci that are related to gastric ulcer, duodenitis, and gastric atrophy caused strains. Sudan-11 strain represents a cancerous strain. Secondary structure referred to strain $26695^{(21)}$. 


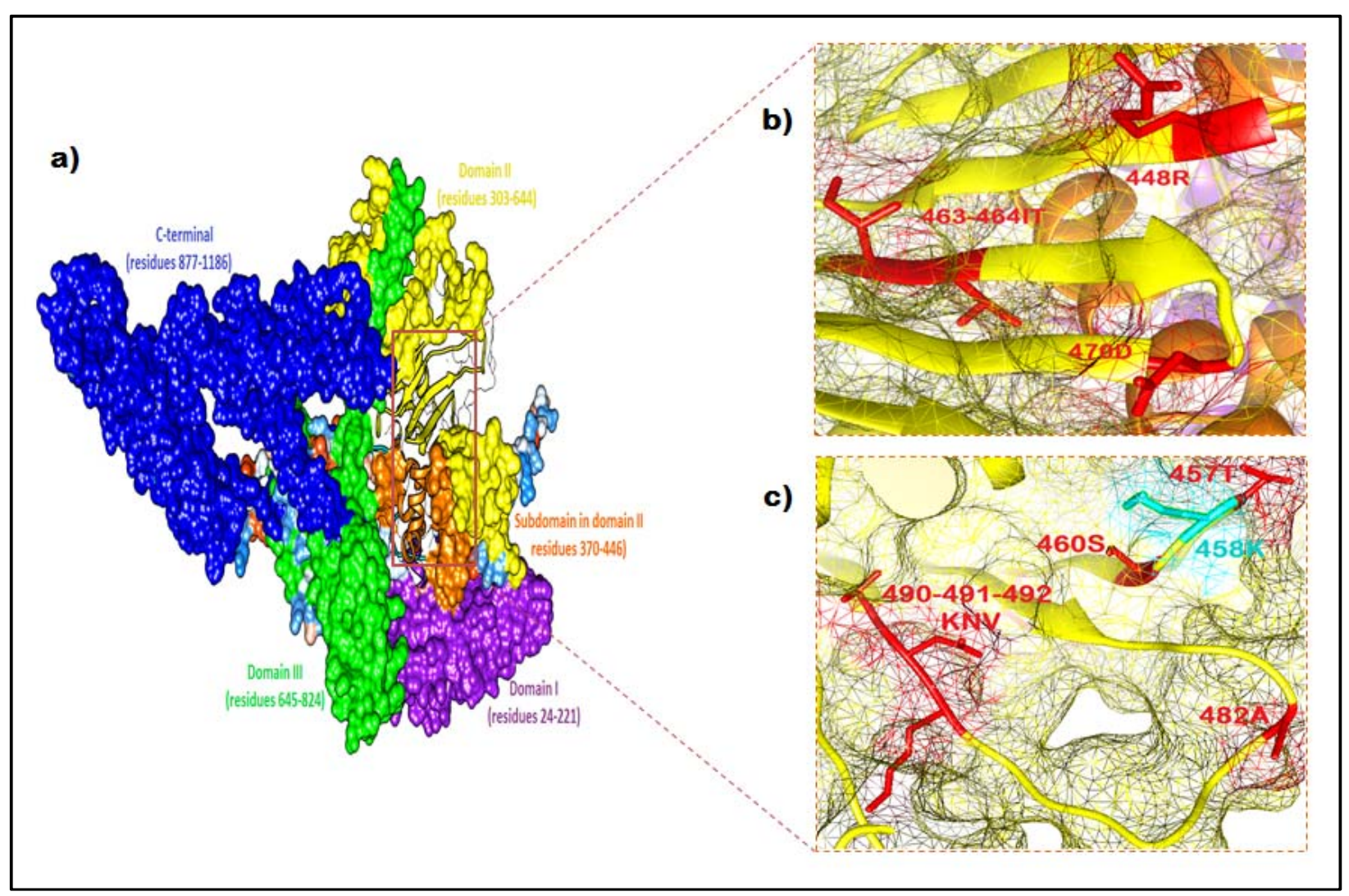

Figure 4: a) Structural homology modeling of cagA derived from $H$. pylori strain $26695^{(20)}$. b) and c) Shows loci of specific- disease mutations observed in duodenitis, ulcer, and atrophy gastric strains. The cyan color represents the locus of the significant novel amino acid substitution $(458 \mathrm{~K})$ in duodenitis strain. 


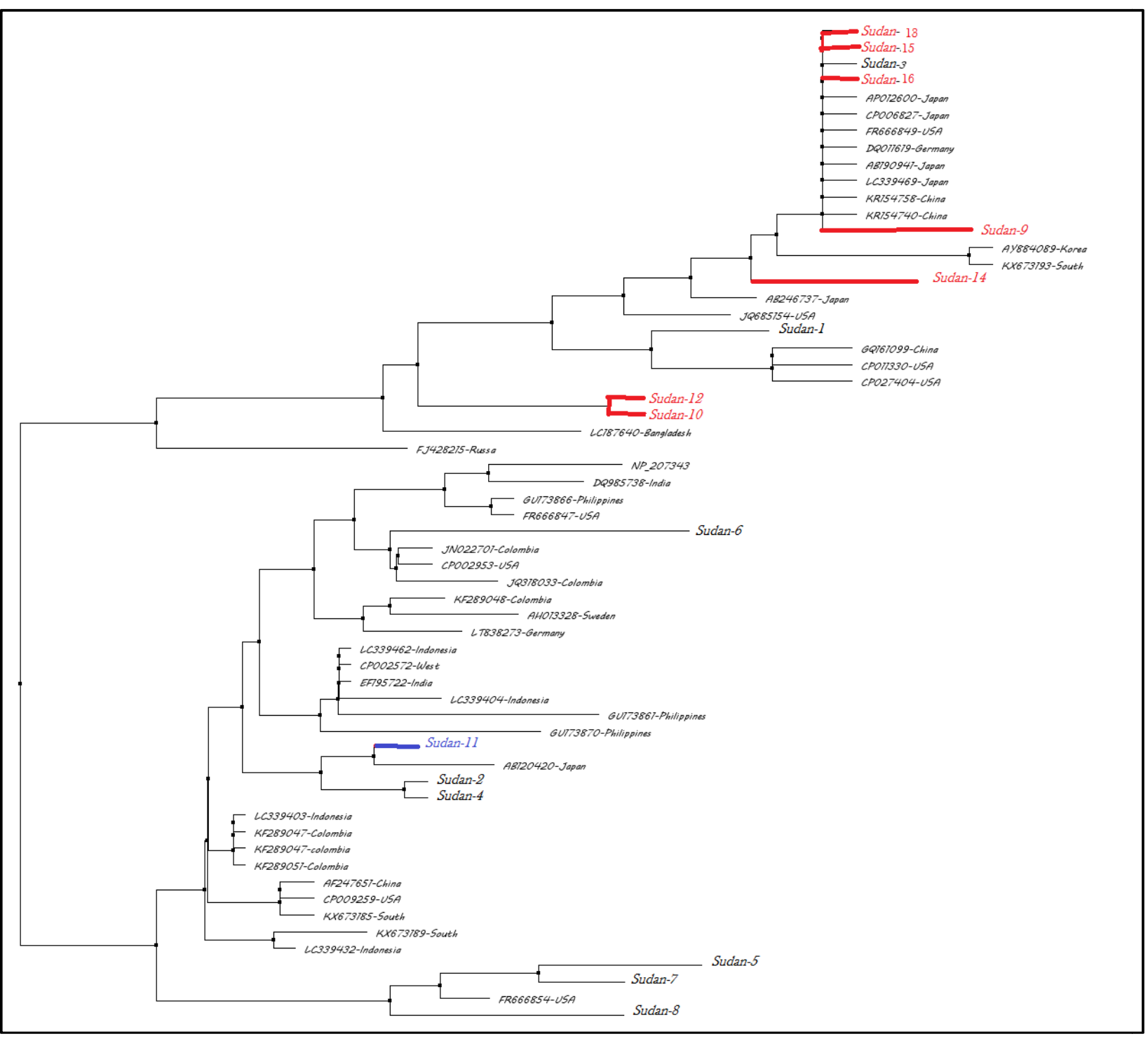

Figure 2. The neighbor-joining tree for the Helicobacter pylori cagA gene of 16 Sudanese strains compared with 20 global reference strains from the Gen Bank database. The Sudanese strains are divided into two major groups Strains that cause duodenitis, gastric ulcer and gastric atrophy are colored in red while the blue color represents cancerous strain. 